\title{
Why Does a Social Worker Act in a Fanatic, Cynical, or Composed Manner? On the Relationship Between Spirituality and the Moral Attitude towards What Cannot Be Changed Vojtěch Šimek
}

\section{Introduction}

For the social worker (further SW), spirituality is important. In the Czech context this is evinced by the overview study The Situation of the Discourse of Spirituality in Social Work, published in 2015, which briefly maps the transformations of social work's relationship to spirituality, in the USA and the Czech Republic. ${ }^{1}$ Regarding the Czech Republic, the study presents, among others, a crucial finding: since 2008, the discourse of spirituality in social work has been gaining momentum. ${ }^{2}$ One of the theoretical expressions of this is, for example, the monograph of 2012 called Spirituality in the Helping Professions. ${ }^{3}$ Regarding empirical investigations, let me mention the paper The Phenomenon of Spirituality and Its Integration into Social Work Curricula of 2010, ${ }^{4}$ which shows the importance of the issue of spirituality not only for SWs, but also for social work students. The paper concludes with the following appeal: 'The task academics face today is not to be afraid to talk to students [of social work] about spirituality, while at the same time it is necessary to find a way of incorporating a content into the curriculum which will (...) equip future [SWs] with the skill of reacting to the needs of clients in the best way possible."5

But to speak and think of spirituality is possible only insofar as the concept 'spirituality' is defined. In what meaning do I use the term 'spirituality' here? ${ }^{6}$ With respect to SWs, the abovementioned

Jan KAŇÁK, Postavení diskursu spirituality v sociální práci, Sociální práce / Sociálna práca 4/2015, pp. 30-46.

Cf. ibid., pp. 41-42.

Zdeněk VOJTÍŠEK, Pavel DUŠEK and Jiří MOTL, Spiritualita v pomáhajících profesích, Praha: Portál, 2012.

Alina KUBICOVÁ, Fenomén spirituality a jeho integrace do osnov sociální práce, in: Rizika sociální práce, ed. Martin SMUTEK, Friedrich W. SEIBEL and Zuzana TRUHLÁŘOVÁ, Hradec Králové: Univerzita Hradec Králové, 2010, pp. 459-464.

5 Ibid., p. 464.

6 At present, spirituality is sometimes understood in a simplified way as an opposite to religiosity. According to this understanding, spirituality is a purely individual and non-institutional expression of the person's relationship to Meaning/Transcendence/the Sacred/ God, while religiosity is a purely social and institutional adherence to some spiritual tradition / religion / church. My assumption here, on the other hand, is that the contents of the concepts 'spirituality' and 'religiosity' generally overlap, i.e., that 'religiosity [frequently is] a subset of spirituality, [...] one (most distinctive, fairly easily graspable and usually investigated) [expression of] spirituality'. The spirituality of some person is normally 'nourished in its entire breadth from one spiritual tradition (from one religion)', but of course it is also possible (and widespread in the contemporary Western world) that someone's personal spirituality does not coincide (entirely/ at all) with adherence to some spiritual tradition / religion / church. So, there can be a spirituality without religiosity, but also (at least hypothetically) a religiosity without spirituality. For more see Zdeněk VOJTÍŠEK, Spiritualita, in: Zdeněk VOJTÍŠEK, Pavel DUŠEK and Jiří MOTL, Spiritualita v pomáhajících profesích, pp. 25-31. 
study distinguishes between 'secular spirituality' and so-called 'sacred spirituality'. The former is a spirituality for which a relationship to the Sacred/God is not necessary. The latter necessarily involves such a relationship. It is worth noticing that, according to that study, an essential characteristic of secular spirituality is 'searching for the meaning of life'. At the same time, the study in this context introduces the ideal that in fact everyone has a spirituality in this sense, 'since searching for meaning is proper to all humans.' This implies that spirituality in the sense of searching for the meaning of life, albeit implicitly and unconsciously, is proper to all SWs, because every SW is human. The author of the study does not explicitly draw this conclusion. But for the present paper it is the first step towards defining the concept of spirituality as employed by me.

But someone might object: searching for the meaning of life is not proper to all humans, or not to all SWs. And if that were the case, then this is not an appropriate point of departure for defining spirituality. The first objection can probably best be answered with reference to Frankl's concept of will to meaning. Frankl, a professor of neurology and psychiatry, claims that will to meaning is a fundamentally anthropological phenomenon, i.e., not only valid for all humans, but furthermore an essential attribute of humanity and a need sui generis, empirically established. ${ }^{8}$ So the first objection appears to be irrelevant. But is the will to meaning an appropriate point of departure for defining spirituality?

With reference to Frankl's concept the answer is affirmative. According to Frankl, the will to meaning is one of the universal aspects of human self-transcendence. ${ }^{9}$ And if human self-transcendence is an essential expression of his spirituality, then the will to meaning is a universally valid aspect of spirituality. Miloš Raban, a recently deceased Czech Frankl scholar, goes even further to claim that the concepts of meaning (of life) and spirituality coincide; they 'express ultimately the same. ${ }^{10}$ In the present paper I employ the term 'spirituality of a SW' in this universally valid meaning - searching for an objective meaning of life. Although Frankl conceived meaning also as subjective, thus unique for each person and situation, he nonetheless emphasised that the meaning of life cannot be 'created' but must be 'found. ${ }^{11}$ But is searching for an objective meaning of life as a central aspect of the spirituality of a SW in some way related to the SW's moral attitude towards what the SW cannot change? That is a crucial question.

In this paper, I assume that such a relationship exists. And I will attempt to show that this relationship is significant for the SW's personal practice. I will restrict the investigation to the SW's moral attitude to what the SW cannot change and bothers him about the person of the client (intrinsic 'unchangeable') and/or the client's situation (extrinsic 'unchangeable'). We are informed by experience that precisely what we cannot change and bothers us is usually more challenging morally, since we normally try to find the meaning of that 'unchangeable. ${ }^{12}$ I conceive 'moral attitude' as

7 Jan KAŇÁK, Postavení diskursu spirituality v sociální práci, p. 33.

8 Cf. Viktor E. FRANKL, Utrpení z nesmyslnosti života: Psychoterapie pro dnešní dobu, Praha: Portál, 2016, p. 15. ‘... the will to meaning is a motivation sui generis, which can neither be reduced to other needs nor deduced from them.' For more on the empirical corroboration see Viktor E. FRANKL, Vưle ke smyslu: Vybrané přednášky o logoterapii, Brno: Cesta, 1994, pp. 11-12.

9 "Using the motivational-theoretical concept "will to meaning" I try to grasp one aspect of self-transcendence, the principal fact that the human being reaches beyond oneself to some meaning which needs to be fulfilled - and first discovered.' Viktor E. FRANKL, Viule ke smyslu, p. 11. From the point of view of philosophical anthropology, self-transcendence is one of the three main metaphysical characteristics of the person. Norris W. CLARKE, Osoba a bytí, Kostelní Vydř́i: Karmelitánské nakladatelství, 2007.

10 Miloš RABAN, Duchovní smysl člověka dnes: Od objektivního k existenciálnímu a věčnému, Praha: Vyšehrad, 2008, p. 193.

11 Cf. Viktor E. FRANKL, Utrpení z nesmyslnosti života, p. 25. 'What can be created is either a subjective meaning, or the mere feeling of a meaning - or non-meaning. Then it is also understandable that the human being who is no longer to find meaning in his life and at the same time is unable to invent it is running away from the feeling of non-meaning of life and begets either non-meaning, or a subjective meaning. (...) the danger arises that in his life the human being will miss the true meaning, the true tasks out there in the world (which differ from merely subjective experiences of meaning in oneself).

12 I do not mean to claim that it is not possible to take a moral attitude to what we cannot change and does not bother us and to relate it to 
the attitude of a person who activates his conscience ${ }^{13}$ and approaches the intrinsic and/or extrinsic 'unchangeables' also through personal virtues or vices.

But how are we to grasp the relationship between searching for an objective meaning of life as a central aspect of the spirituality of a SW and the SW's moral attitude towards what the SW cannot change? I will attempt to do that in the first part of this paper using the inspiring typology of the German philosopher Robert Spaemann. It is the basic typology of the fanatic, the cynic and the composed Stoic. The typology can serve students of social work or SW ${ }^{14}$ as a primary framework for reflecting upon their spirituality in the central aspect under consideration. I was inspired to this by the idea of the Czech religious studies scholar Zdeněk Vojtíšek, who writes in the abovementioned monograph that 'the spirituality of an individual human being' is 'the source of his problems.' ${ }^{15}$

But how about those SWs who experience spirituality in the second of the abovementioned meanings (sacred spiritualita), i.e., a relationship to the Sacred/God is a necessary condition of their spirituality. Are they also searching for the meaning of life? It is evident that sacred spirituality also implies the central aspect concerning the meaning of life. However, religions - at least the three largest monotheistic ones (Judaism, Christianity and Islam) - are generally not concerned with searching for meaning, but with accepting the meaning which is given by the respective conception of God. In this paper, I will restrict sacred spirituality to Christianity, in which the objective meaning of life is given by the specific Trinitarian conception of God and fulfilled in Jesus Christ. In one of his texts the Czech theologian Michal Opatrný, who focuses on the relationship of Christian theology and social work, briefly touches on the issue of meaning and holds that the possible source of problems for the SW can be not relying on Christ. ${ }^{16}$

In the second part of the paper I will therefore attempt to supplement the abovementioned typology with the type of composed Christian and reflect on the Christian relying on Christ, and, by means of examples, attempt to outline the relationship between relying on Christ on the part of the Christian SW and his moral attitude towards what he cannot change and bothers him. This part also offers a starting framework for possible self-reflection, this time to those SWs who are Christian or interested in Christianity. Christians are still a strongly represented group in Europe and many organisations engaging in social work more or less explicitly appeal to Christian moral principles.

the issue of the meaning of life. We do so, often implicitly, but sometimes also explicitly. For example, I am a man, I cannot change it and it does not bother me (in fact I am happy to be one). Nonetheless, I take, at least implicitly, a moral attitude to that given by accepting it as a meaningful basis for my personal life and development. But what I cannot change and (for whatever reasons) bothers me is a morally specific and more demanding challenge, because it is difficult to accept it as meaningful point of departure of personal life and development.

13 According to Frankl, the conscience is the 'organ of meaning', 'a part of condition humaine', a tool with which the human being searches for and discovers the objective meaning of life. Viktor E. FRANKL, Utrpení z nesmyslnosti života, pp. 25-26..

14 For the sake of simplification, I use the abbreviation SW for male and female social workers and male and female students of social work. Let us assume the hypothesis above for both groups, although it can have a different meaning for each - primarily a theoretical one for the students, mostly a practical one for the workers. It is highly beneficial for members of both groups not to be limited to one of them. The workers ought to continue studying, the students ought to experience the practice in the field they are studying.

15 Zdeněk VOJTÍŠEK, Cesty pomoci v potížích se spiritualitou, in: Zdeněk VOJTÍŠEK, Pavel DUŠEK and Jiří MOTL, Spiritualita $v$ pomáhajících profesích, p. 49. 'So, essentially the only unavoidable condition of quality help we see is the reflection of the helper's own spirituality we have already mentioned several times, best performed with the help of a supervisor.' Ibid., p. 68.

16 'The Christian as a helper can declare faith in Christ, but he need not really rely on him in his work. He can claim that it is meaningful to do the good, but at the same time not rely on the good and the One from whom it originates. The helper then wants to have absolute control over the client - he does not believe that the meaning which carries him can carry the client too, so that he gives the client no chance to let himself be carried. Or the other way round: because the helper does not rely on the meaning which carries him and his work, he cannot rely on the client to perform the task he has been entrusted with or not to repeat his error. I believe that this "reliance on God" is one of the most basic aspects of the Christian faith...' Michal OPATRNÝ, Třináctá komnata vztahu teologie a sociální práce: K problematice negativních vlivů křestanské víry na pomáhání, Caritas et veritas 1/2011, pp. 57-58. 
This paper is based in philosophical and theological anthropology and ethics. I assume that the theory of social work (as an academic discipline) necessarily needs both anthropology and ethics, in the philosophical and theological dimension, if it is to adequately investigate spirituality. To begin I would also like to add that I am aware that spirituality is a complex phenomenon. I have merely chosen one of its aspects, which, while I regard it as central, is not the only one. ${ }^{17}$ I am interested in the rational aspect of spirituality, insofar as it influences the volitional, moral aspect of the person. ${ }^{18}$

\section{The fanatic, the cynic, and the composed Stoic}

Before I employ Spaemann's typology to focus on the relationship between searching for the objective meaning of life as a central aspect of the spirituality of a SW and the SW's moral attitude to what the SW cannot change, I will attempt to very briefly sketch the basic kinds of unchangeables to which every human being is subjected, and also how they can in general project onto social work. Since conception, every person is determined by intrinsic unchangeables: a unique genetic makeup, which implies certain (pre)dispositions, sex, etc. The extrinsic unchangeables include the biological parents, the time and place of the person's conception/birth, the country, culture and social environment where the person grows up and is formed, etc. Upbringing and education bring about passively caused unchangeables, as well as actively acquired unchangeables by how the person is passively formed and also how he actively forms himself. From the active point of view, each past decision and action of the person becomes something that cannot be changed and by which the person forms himself within the scope of his intrinsic and extrinsic unchangeables. There are: lifelong unchangeables, for example, genetic (pre)disposition; long-term unchangeables, such as, the moral character (the older the person is, the more difficult and long-lasting a change is); and short-term unchangeables, for example, being ill with the flu, etc. The long-term and shortterm unchangeables sometimes derive from the lifelong ones, and sometimes they arise from a combination of different causes and circumstances. As I have stated above, in general these (and other possible) kinds of unchangeables can be divided into those that bother the person and the ones that do not bother him. ${ }^{19}$

The nature of social work implies that it focuses on social change within the scope of the clients long-term and short-term unchangeables. It is evident that the clients' lifelong unchangeables cannot be changed. I believe that social work typically strives to change the long-term and short-term unchangeables within the scope of the clients' generally unfavourable lifelong/long-term unchangeables. However, the SW frequently cannot directly influence even the long-term unchangeable (whereby he knows that the success of the social work with the client fully/partially depends on it). At the same time, the SW frequently finds himself in situations where certain (for the given social case typical) long-term/short-term unchangeables bother him, while they do not bother

17 Vojtíšek expresses the complexity of spirituality with a seven-level model. The central aspect I am analysing here corresponds to the first level - the premises of spirituality ('These are doctrinal and philosophical conceptions which explain the world for the human being, facilitate orientation in it and give meaning to his life.), but with respect to the impact on practice also to the third level - the norms and values determining the person's moral attitude. Besides these two levels, Vojtíšek's model includes the level of rites $\left(2^{\text {nd }}\right)$, narration $\left(4^{\text {th }}\right)$, experience $\left(5^{\text {th }}\right)$, community $\left(6^{\text {th }}\right)$ and creativity $\left(7^{\text {th }}\right)$. Zdeněk VOJTÍŠEK, Spiritualita, in: Zdeněk VOJTÍŠEK, Pavel DUŠEK and Jiří MOTL, Spiritualita v pomáhajících profesích, pp. 19-22.

18 Vojtíšek adds that this (static) model of the complexity of spirituality must be supplemented with a 'dynamic, volitional dimension' concern, loyalty. That absolutely corresponds to the basic powers of the human person, who has not only the intellect and emotions, but also the will. Cf. ibid., pp. 22-23.

19 It is very interesting that whether and how much a person is (not) bothered by an unchangeable is again due to that person's specific unchangeables, for example, his moral character, nature, inclinations, but also the religious, cultural and social milieu he lives in. 
the client (an example may be social work with a client addicted to drugs; his addiction is usually a function of the social milieu where the client lives; the setting mostly does not bother the client, because he may feel good in it; it does bother the SW, on the other hand, because he knows that only a different environment will enable the client to overcome the addiction). In general, it can be judged that the $S W$ frequently finds himself in situations when he is confronted with a number of clients' lifelong, long-term-and short-term unchangeables which he finds difficult to accept. Is there a relationship between the central aspect of the SW's spirituality, namely searching for the objective meaning of life, and his moral attitude towards these unchangeables?

(a) The fanatic believes that the meaning of life exists only as given and realised by him. He places his subjective meaning of life against reality and believes that no objective meaning of life exists. He thinks that 'the world becomes meaningful only with his action. ${ }^{20}$ If he encounters some changeables that bother him, he is reluctant to accept them and generally reacts by rejecting them, denying them or trying to change them. In the moral respect, he becomes a subjectivist. 'A fanatic is one who says with Hitler: If we perish, world history will become meaningless.'21

The fanatic $S W$ finds it very difficult to accept all kinds of clients' unchangeables that bother him. He reacts by rejecting them, denying them, or by ill-considered attempts to change them. Instead of accepting the unchangeables and beginning to work with them in a constructive manner, he loses time and energy ignoring or denying them, or even making dangerous attempts to change them. The fanatic SW is convinced that it is he who brings meaning to the client's life. If he 'doesn't help' the client, then the client's life will lose meaning. From the moral point of view, illicit interventions into the client's autonomy regularly occur. From the psychological point of view, the fanatic SW prefers to focus on submissive clients who will believe that only the SW will help them.

Let me give simple examples of the moral attitudes of the fanatic $S W$; the first one concerns an intrinsic unchangeable of the client while the second regards an extrinsic one:

- The SW is bothered by the client's specific behaviour. Rather than accepting the fact that the client is mentally ill (and beginning to work with the client in a manner adequate to that), he more or less ignores the fact and approaches the client as if it was a matter of a temporary instability, whereby he persuades the client that he must overcome it.

- The SW strives to take a child away from a family where there are impaired conditions for the child, but where the child at the same time has both important reference persons which he needs for normal psychological development (his own father and mother). The SW is subjectively bothered by the impaired conditions in the household and fanatically regards them as a more important criterion that the objective criterion of the presence of the father and mother.

(b) The cynic is the opposite of the fanatic; he does not place his subjective meaning in an opposition to reality, but reality in an opposition to all meaning. However, he agrees with the fanatic on one point: no objective meaning of life exists - 'the reality surrounding our actions, which precedes them and into which our actions flow, is meaningless.'22 According to the cynic, all that happens is based on chance, it is meaningless to seek for an objective meaning in anything or to give

20 Robert SPAEMANN, Moralische Grundbegriffe, München: C. H. Beck, 8. ed., 2009, p. 102. There is also a Czech translation; here I work with the German original.

21 Ibid.

22 Ibid., p. 103. 
a subjective meaning to anything. ${ }^{23}$ Nonetheless, a cynic does paradoxically 'believe' in the right of force. If he encounters some unchangeables that bother him, he normally reacts with scorn, or the claim that 'such is life, let us not look for anything more in it.' He views all that happens as mechanic; he is usually a convinced materialist, and in the moral respect a nihilist.

The cynical $S W$ is often a 'cured' fanatic who has found out that the reality against which he was 'fighting' was stronger. While the fanatic denied, rejected or dangerously tried to change the client's unchangeables, the 'enlightened' cynic resigned. But in the case of the cynic it is not a matter of realistically accepting the client's unchangeables, but of trivialising them. Although the cynic, unlike the fanatic, does not lose time making dangerous attempts to 'change' the client's unchangeables, he also loses no time with the client because he thinks that it is meaningless anyway. The cynic believes that it is meaningless to help the client at all. Even if (someone) helped the client, it would not secure success in the long run. From the moral point of view, the cynic frequently engages in illicit trivialisation or nihilism, or scepticism. The cynic may frequently neglect the clients, be cruel, or do the work only 'for show'. From the psychological point of view the cynical SW focuses on clients who 'make no problems'.

Let me now modify the examples above to outline the moral attitudes of a cynical $S W$; the first relates to an intrinsic unchangeable of the client, and the second to an extrinsic one:

- The SW does not deny that the client is mentally ill, but uses it to his own profit whenever he can (according to the 'right of force').

- The SW does not strive to take the child away from the family by subordinating objective criteria to subjective ones, but on the other hand he makes no effort to improve the impaired conditions in the family in any way, or help to improve them ('it is meaningless anyway'). If other colleagues become involved in the case, who are fanatics and place their subjective points of view above the objective one, he remains neutral or cynically takes the colleagues' side.

Probably no properly committed ${ }^{24} \mathrm{SW}$ consciously wants to be a fanatic or a cynic. Why? Because it is unreasonable to ignore or trivialise what cannot be changed. No reasonable human being will deny that it ought to be accepted, since by ignoring it trivialising it we will not change it anyway. It is a part of reality and it is possible to act reasonably only insofar as we accept reality and make it the foundation of our action. Therefore, the fanatic and the cynic do not act reasonably.

(c) The Stoic appears to be reasonable, because he accepts all that life brings. He lives by the maxim 'Want the things that are happening and you will always be satisfied. He appears to be composed and free, but at the cost of entirely giving up his emotions. For wanting the things that are happening at all times implies that all that is happening and bothers me in fact must not bother me. That is why the Stoic's ideal is dispassion. The Stoic must sacrifice subjective meaning to a certain conception of objective meaning. But the Stoic objective meaning is fatalistic: it is an inexorable law to which the Stoic must conform: 'he must follow it, must obey it. He must believe that

23 It is possible to object to this using an infinite regress: Why is it meaningless to look for / give something meaning? Because it is meaningless? But how is that to be established? Why is it meaningless that it be meaningful to search for / give something meaning? The infinite regress forces the cynic to realise that he is relying on a principle of 'meaninglessness', which is ungrounded, unjustified. So ultimately even the cynic 'believes' in something.

24 According to Karel Kopřiva, non-committed SWs find their work meaningless. Cf. Karel KOPŘIVA, Lidský vztah jako součást profese, Praha: Portál, 2006, p. 16. A non-committed SW is therefore more or less a cynic. A SW who does find meaning in his work, but only such that he brings into it himself, on the other hand, is a fanatic. 
all that happens necessarily had to happen and must not reproach himself for anything... ${ }^{25}$ And while in the moral respect the Stoic strives for supra-human patience, he lacks the motivation to change the things that can be changed and which it is right to change for the better. Some Stoics even condemned compassion. ${ }^{26}$

The Stoic SW may be an 'awakened' cynic or fanatic who assumes a fatalism of some kind. He 'believes' in an objective meaning of life, which 'works' deterministically and the human being has no option but to subordinate himself to it (whether he wants to or not). The Stoic SW bears everything about the client with supra-human patience, even the things that had better be changed, and tries not to see a difference between what bothers him and what does not. If all that has happened to the client happened necessarily, is the state he is in just? In practice, the Stoic SW may resemble the cynic, but differs from him in that he finds an objective meaning in the fatalistic course of events. However, it cannot be changed, one must conform to it. So why should one help the client, why help him change his life? If the Stoic SW lacks morally relevant compassion, it may be a vital shortcoming for some kinds of social work.

Let me now modify the examples above to sketch the moral attitudes of the Stoic SW; the first relates to an intrinsic unchangeable of the client, the second to an extrinsic one:

- The SW accepts the client's mental illness, but has no compassion for him and does nothing to alleviate the condition.

- While the SW makes the effort to unjustly take the child away from his family, he also makes no effort to ameliorate the impaired conditions in the family.

Of the three attitudes described above, the Stoic moral attitude is evidently the best in that it accepts reality and teaches one to be reconciled to what cannot be changed and bothers him. But as we have seen, Stoicism also involves some shortcomings. Without pretence to a detailed criticism of Stoicism, I would like to point out the two main shortcomings of Stoicism as a certain type of the central aspect of spirituality. First, the Stoics taught that the human being ought to act in accordance with his nature. ${ }^{27}$ But passions are a part of human nature. So, acting in accordance with human nature cannot imply dispassion, apathy. ${ }^{28}$ The second shortcoming is concerned with being reconciled to everything. The Stoics taught agreement of the will with the things that are happening. But not all that happens is morally right. If we must not want what is morally wrong, then we must not want all that is happening.

\section{The composed Christian and reliance on Christ}

With the help of Spaemann's typology we have seen some basic links between (not) searching for an objective meaning of life as the central aspect of the spirituality of an SW and the SW's moral attitude towards what the SW cannot change. In the fanatic and the cynic, it is more appropriate to speak of denying, rather than 'not searching'. I raised objections against that in note 23 above using infinite regress and suggested that the spiritual assumptions of the meaninglessness of life

\footnotetext{
SENECA, Dalš́ listy Luciliovi, Praha: Svoboda, 1984, p. 232.

Cf. Robert SPAEMANN, Moralische Grundbegriffe, p. 104.

SENECA, Další listy Luciliovi, p. 232.

28 Cf. Robert SPAEMANN, Moralische Grundbegriffe, p. 104. But the passions/emotions must be appropriately formed by the intellect, as Aristotle had already pointed out.
} 
in the cynic are a kind of 'faith' - in a certain (meta...)meta-meaninglessness, which he no longer proves but believes in. In the case of the fanatic the situation is similar. The fanatic believes that he is creating objective meaning by his subjective meaning, which he must in turn ground in something. And because he also cannot proceed indefinitely, he also postulates some subjective (meta...)meta-meaning, which he no longer proves but believes in. ${ }^{29}$ So although fanaticism and cynicism can be designated as secular spiritualities, we can see that they have some (pseudo)religious basis.

Although the Stoic conviction is primarily a philosophical one, it also derives from a kind of 'faith', namely from pantheism. The Stoic, unlike the fanatic and cynic, does not deny an objective meaning of life. But Stoic pantheism sacrifices the subjective meaning to a fatalistic conception of objective meaning. Although the Stoic objective meaning of life requires reconciliation, it is at the cost of a whole number of shortcomings. Stoic fatalism can also be designated as a secular spirituality, although it also has a religious foundation. It is the 'faith' in the 'logos' (reason), an impersonal, eternal, all-determining principle. From pre-Christian and non-Christian philosophy, the concept of 'logos' was adopted into Christian philosophy and theology and gained a specific meaning by becoming a designation for the second divine person, Jesus Christ, albeit capitalised - 'Logos' (cf. John 1:1). In our context, Christianity is a specific form of sacred spirituality, in which the objective meaning of life for every human being is precisely the Logos. ${ }^{30}$ Let us now take a brief look at the basic specific characteristics of Christian reconciliation/composedness and reliance on Christ, first in general, also in comparison with the Stoic, then in examples from the sphere of social work. Compared to the Stoic, the Christian differs in that he tries to integrate passions/emotions. He cultivates them with the help of reason and will, but does not rely only on the natural light of reason, but also on supernatural light, i.e., on faith, the light of the Holy Spirit. ${ }^{31}$ The will is governed by reason (the judgment of the conscience) and together they can make use of the three theological virtues faith, hope, and charity. These virtues are 'infused, i.e., such that the Christian cannot attain them by natural powers. The three theological virtues help to perfect the four natural virtues - prudence, justice, courage and temperance. According to the perfection of these seven virtues, the Christian approaches the things he cannot change and which bother him. Unlike the Stoic, he certainly does not strive to annihilate the difference between what bothers him and what does not. In the light of prudent faith, he gradually learns to distinguish between what ought (not) to bother him and in what order. The Christian is not composed so as to be indifferent to whether he will be able to realise his intentions, for unlike the Stoic he does not strive for apathy (dispassion). But on the other hand, he, unlike the fanatic, does not force through the realisation of his purposes at all cost.

From the outside, the Christian can closely resemble the Stoic in that he gradually ceases to be bothered by many of the unchangeables. But the core of the difference consists in that the Christian is not impassive, but, empowered by the Holy Spirit, is capable of bearing (some of) the difficult and painful things. Christian reconciliation is characterised by a new kind of supernatural motivation and a supernatural power to bear what cannot be changed. However, the Christian ought

29 I am not saying here that each infinite regress can be solved only by a 'faith' in some first principle. I use the label 'faith' (in inverted commas) to designate cases when some first principle is blindly accepted without critical proof. From the philosophical point of view, it is possible and desirable that even first principles be proven by so-called indirect proof.

30 Christian philosophy and theology is specific also in that the objective meaning of life is not primarily 'discovered' by the human being; rather, the human being is 'addressed' by the objective meaning, which is the Logos. That, however, does not imply complete passivity on the part of the human being.

31 The Holy Spirit is the third divine person, besides the Father and the Son (Jesus Christ - Logos). The Father is the Origin of (Christian) existence. The Holy Spirit proceeds from Father and Son. However, according to Christian theology, the three divine Persons share one nature (they are one God) and therefore act always together. 
not to take the part of the aching sufferer; insofar as is possible, he normally tries to remove pain, suffering and evil (and prays for this), but when this is not possible, he tries to imitate Christ in acceptance and composedness (cf. Lk 22:42). ${ }^{32}$ The Christian's (effort at) reconciliation to lifelong/ long-term unchangeables that bother him or cause him pain is directly proportionate to his faith and trust in God, who looks after their intensity and extent and has good(!) reasons to permit them (cf. 1 Cor 10:13). ${ }^{33}$ And the ability to bear all that is directly proportional to the strength of the Christian's (supernatural) charity (cf. 1 Cor 13:7). ${ }^{34}$

What does the Christian's reliance on Christ consist in in this context? First of all, in the abovementioned faith and trust, i.e., it is essentially an act of the intellect and the subsequent agreement of the will. This reliance on Christ is gradually transformed into patience and courage, and affects the other virtues as well. It is crucial that with respect to the long-term/short-term unchangeables, which the Christian, upon mature reflection and prayer, had attempted to change but it was not possible, reliance on Christ eo ipso becomes at the same time suffering with Christ. At the level of the intellect it is a matter of relying on Christ that He gives the unchangeables meaning (even if the Christian perhaps sees no meaning in them at present!), at the level of the will, emotions and the body generally it is a matter of bearing the given unchangeables with Christ, in the power of His Spirit. In this profound sense, Christian spirituality is understood by right as not only what the Christian does alone, but also as what the Holy Spirit does in the Christian! ${ }^{35}$ And yet it is not merely a matter of passivity, so that even bearing and suffering is a certain form of acting. ${ }^{36}$ The ratio of passivity and activity can vary, but it is never a fatalistic passivity; on the contrary, the Christian can suffer actively, in the profound sense indicated above - and thereby paradoxically attain a deep inner peace even in the midst of great pain and hardship.

The relationship between objective and subjective meaning is therefore different in the Christian than in the Stoic. The Christian, aware of his Christian freedom (cf. 1 Cor 3:21-23), ${ }^{37}$ approaches his life and the world actively, without fear and with trust in the divine power, but at the same time accepts all he could not change as a divine invitation to suffer with Christ (which is also a change in the world an alternative and more profound one). Between the subjective meaning, which is controlled by the Christian, and the objective meaning, which is controlled by (and is) Christ, there is dialogue. The Christian does not think that it is he who brings meaning into the world, but on the other hand he also does not think that it is enough to be passively led by God like a puppet. It is a living dialogue, a relationship, often even 'a struggle with God', something principally different from the Stoic's effort at harmonisation with the impersonal logos. And it is appropriate to add that a real and practically lived Christian spirituality is never a merely intellectual matter or a merely emotional, experiential one, etc., but includes all dimensions of the person, gradually filled by the Spirit of God. ${ }^{38}$

32 'Father, if thou art willing, remove this cup from me; nevertheless not my will, but thine, be done.'

33 'No temptation has overtaken you that is not common to man. God is faithful, and he will not let you be tempted beyond your strength, but with the temptation will also provide the way of escape, that you may be able to endure it.'

34 'Love bears all things, believes all things, hopes all things, endures all things.'

35 Cf. Vojtěch KOHUT, Spiritualita, in: Stefano DE FIORES and Tullo GOFFI (ed.), Slovník spirituality, Kostelní Vydří: Karmelitánské nakladatelství, 1999, p. 905.

36 Cf. Robert SPAEMANN, Moralische Grundbegriffe, p. 101.

37 'For all things are yours, whether [...] the world or life or death or the present or the future, all are yours; and you are Christ's; and Christ is God's.'

38 Cf. Walter H. PRINCIPE, Spirituality (Christian), in: Michael DOWNEY (ed.), The New Dictionary of Catholic Spirituality, Collegeville: The Liturgical Press, 1993, p. 931. Concerning Christian spirituality, I must point out that I have merely very briefly attempted to sketch some of its essential features. Within Catholic spirituality there is an immense number of different spiritualities (monastic, priestly, lay), some of which again branch into further kinds and forms. But the plurality of spiritualities within (Catholic) Christianity is desirable and in fact necessary, because it is an expression of different charisms and different manifestations of the same Holy Spirit with respect to different times, needs and circumstances. 
How is the composedness/reconciliation of the Christian SW expressed? Returning to the two examples given above, it is possible to roughly sketch his moral attitudes as follows:

- The SW accepts the client's mental illness, strives for compassion with the client and makes an effort to approach the client in an adequate way.

- The SW does not make an effort to unjustly take the child away from the family and actively strives to ameliorate the impaired conditions in the family.

I will supplement these simple illustrative examples with two more interesting ones, deriving from my own experience with social work. Hopefully, they will make more apparent the relationship between relying on Christ and the moral attitude to what cannot be changed and is difficult. The SW takes care of a client suffering from Alzheimer's disease in a late stage as if he were a baby, including personal hygiene. The client is in a late stage of a neurodegenerative brain disease and has ceased to communicate. In the course of regular personal hygiene in the shower, the client frequently cannot control his bowels and because he is no longer able to communicate, the situation always takes the SW somewhat by surprise and it is mentally and humanly demanding for him. The situation arises frequently, it is not easy to prevent and is an unchangeable which bothers the SW. From the natural, human point of view, the SW tries to rationalise the situation, makes no reproaches to the client and is aware that the client is not guilty of the situation due to his medical condition. But that does not improve the SW's situation very much, so the SW as a Christian relies on supernatural power to help him bear the repeated situations with patience and reconciliation. It is a gradual process, moral maturation at a deeper level, where the SW is learning to rely with his whole person on Christ, who braces his limited human powers. The central aspect of the SW's spirituality, which is believing that the situation has an objective deeper sense, plays a decisive part both in the very beginning of the process, and in its successful duration. An SW who works as a street worker in the church organisation Teen Challenge establishes contact with a client addicted to drugs and offers him a residential one-year-long therapeutic programme, which would enable the client to overcome the addiction and begin an overall process of mental and physical recovery. The therapeutic programme takes place in a Christian setting. The client knows that and precisely for that reason refuses it and places himself in opposition to Christianity with blunt, coarse insults. That bothers the SW because he is a Christian. On the one hand, the SW does not primarily want to 'convert' the client to Christianity, but on the other hand he also does not want to leave him in the addiction and knows that the offered programme could give the client a life chance. But over the course of further meetings the insults continue. The SW knows that he can offer the client other forms of addiction therapy, but has the inner feeling that the client's insults and his defiance of Christianity are probably a mere pose concealing the client's spiritual sensibility for the kind of programme offered. But the SW does not know how to activate that sensibility and channel it in the right direction, while at the same time he is bothered by the client's insults and his coarse manner of communication. Apparently, from a purely natural point of view the SW is not morally obliged to bear the client's insults and look for difficult paths to the client's spiritual sensibility. But on the other hand, he as a Christian believes that the situation has a concealed, supernatural meaning and strives for patience and composedness. He gradually seeks difficult paths to the client's soul and bears his way of communicating. Morally, he relies on the central aspect of his spirituality: he sees an objective, hidden meaning in the situation. 


\section{Conclusion}

The potential of spirituality is both integrating and destructive. ${ }^{39}$ This summary observation simultaneously expresses the conclusion of this paper. I hope that the reader has seen the power of that potential in the course of examining the relationship between the selected central aspect of the spirituality of a SW - (not) searching for an objective meaning of life - and the SW's moral attitude towards what the SW cannot change and bothers him.

The fanatic SW relates to the client in a destructive manner. He believes that he is creating the meaning of the client's life purely by his commitment for the client. He misses the objective reality and its meaning. He finds it very difficult to accept all kinds of unchangeables about the client that bother him. He manipulates the client according to his subjective notions. The cynical SW also relates to the client in a destructive manner, although it might not be quite as apparent. An SW may become cynical when he has become exhausted by fanatically engaging in ill-considered attempts to change unchangeables, by denying them, or by acting in a manipulative manner. $\mathrm{He}$ believes in the right of force, but he views the objective reality as a mechanical course of events devoid of all meaning. While the fanatic inclines towards moral subjectivism, the cynic inclines towards moral nihilism. Deep down in his heart the cynic often believes that it is in fact meaningless to help the client. He often uses the client to his advantage. Most SWs would probably agree that the fanatic's and the cynic's moral attitudes are unreasonable and offer no good prospects, whether professionally or humanly.

For some, the $S W$ who is a composed Stoic can be an attractive type at first glance, probably due to his unswerving dispassion and superhuman patience. But, in fact, the Stoic's moral attitude will be acceptable only for a SW who rigorously takes some fatalistic life stance and places no emphasis on compassion. Compassion, however, appears to be important for social work. Using the Stoic type I have tried to show how spirituality is crucially affected by those elements of a worldview/ religion which explain the issue of the objective meaning of life and the issue of the nature of the highest principle of the universe. The $S W$ who is a composed Christian may externally resemble the Stoic, but there is an essential difference precisely in that the Christian lives his spirituality in a relationship to God who is not a mere impersonal principle of the universe. The moral attitude of the Christian SW will probably be fully graspable only for those SWs who are Christians themselves or are more closely familiar with Christianity.

The non-Christian reader may object that in this paper the composed Christian SW plays the part of a 'SW-superman'. The composed Christian SW is presented as the best type, with the best moral evaluation within the selected examples. That is true. On the other hand, I would like to point out that the selected typology is normatively ideal. In everyday practice, the Christian SW need not be (and in fact sometimes is not) morally evaluated as the best. In everyday practice, the Christian SW can also be endangered or even 'contaminated' with fanaticism, fatalism, or cynicism. Note 16 mentions some of the characteristics of the Christian SW inclining to fanaticism. It is also necessary to add that the typology employed does not cover the entire spectrum of reality and is certainly not complete. It would be interesting to add other types from the point of view of the other two monotheistic religions, Judaism and Islam, or from the point of view of Hinduism and Buddhism. Unfortunately, that is beyond the scope of this paper.

Despite these limits this paper can serve some Czech SWs as a good tool for self-reflection regar-

39 Cf. Zdeněk VOJTÍŠEK, Vybrané teoretické podněty, in: Zdeněk VOJTÍŠEK, Pavel DUŠEK and Jiří MOTL, Spiritualita v pomáhajících profesich, p. 80 . 
ding the basic relationship between (not) searching for an objective meaning of life and the moral attitude towards what cannot be changed and causes difficulties. At the same time, one must keep in mind that the primary goal is not to label oneself or others with one of the presented (or other) types. Typologies are intended to assist particular persons in self-reflection. And self-reflection ought to be a cognitive point of departure for a desirable change in practice. I hope that the paper will successfully serve this purpose in the Czech milieu of the (Christian) theory of social work and will be used, supplemented, and/or critically reflected upon.

In the introduction, I quoted the appeal made by one recent Czech empirical study dealing with investigating the phenomenon of spirituality among students of social work. It was an appeal to academics: do not be afraid to discuss spirituality with students of social work and find a way of incorporating the relevant issues into the curriculum. With this paper, I have attempted to respond to it. I will use the contents of this paper as the foundation text of a lecture for students in the graduate study programme Ethics in Social Work.

\title{
Why Does a Social Worker Act in a Fanatic, Cynical, or Composed Manner? On the Relationship Between Spirituality and the Moral Attitude towards What Cannot Be Changed
}

\begin{abstract}
The author begins by researching Czech relevant sources and contributes to the Czech expert discussion about spirituality and social work. His contribution is based on Christian philosophy and theology. The author analyses some basic relations between the selected central aspect of spirituality of the social worker and his moral attitude to what cannot be changed and what bothers him; the selected aspect is the search for the objective meaning of life. The author shows the relations with a selected typology - a fanatic, a cynic, a composed stoic, and a composed Christian - and offers to social workers and social work students an inspirational typological tool for self-reflection. The general analysis is illustrated with simple examples, also from the author's own experience. The main conclusion is that the spirituality of a social worker, in his moral attitude to what cannot be changed and what bothers him, has an integrating, but also destructive potential. This destructive potential is present in the spirituality of a fanatic and a cynic. To what extent it is possible to talk about an integrating potential in the spirituality of a composed stoic depends on the reader's perspective. According to the author, the greatest potential for integration is in the spirituality of a composed Christian.
\end{abstract}

Keywords: Christianity and social work, social work and spirituality, meaning of life, fanaticism, cynicism, Stoicism

\section{Author contact}

\section{PhDr. Vojtěch Šimek, Th.D.}

University of South Bohemia in České Budějovice

Faculty of Theology, Department of Philosophy and Religious Studies

Kněžská 8, 37001 České Budějovice

simekv00@tf.jcu.cz 